\title{
Anaesthetic management for hydropool recovery in 50 horses
}

\author{
Stephanie Picek, Karin S. Kalchofner, Simone K. Ringer, Martin Kummer, Anton Fürst and Regula Bettschart-Wolfensberger \\ Equine Department, Section of Anaesthesiology and Surgery, Vetsuisse Faculty, University of Zurich, Zurich, Switzerland
}

\begin{abstract}
Summary
This study retrospectively describes the anaesthetic management before and during hydropool recovery in horses. Fifty horses (mean age $113.7 \pm 64.2$ months, mean weight $479.3 \pm 115.3 \mathrm{~kg}$ ) underwent surgery for repair of different long bone fractures and other severe orthopaedic diseases. Thirty-nine horses were starved for 8-12 hours and eleven horses were presented as emergency cases, which needed immediate intervention. Intravenous antibiotics, acepromazine $(0.03 \mathrm{mg} / \mathrm{kg} \mathrm{IM})$ and phenylbutazone $(4 \mathrm{mg} / \mathrm{kg} \mathrm{IV})$ were administered 30-60 minutes before anaesthesia induction. Sedation was achieved using medetomidine $(7 \mathrm{mcg} / \mathrm{kg} \mathrm{IV}$ ) and anaesthesia induction with $2.2 \mathrm{mg} / \mathrm{kg}$ ketamine and $0.02 \mathrm{mg} / \mathrm{kg}$ diazepam IV. Anaesthesia was maintained with isoflurane (in oxygen and air) and medetomidine constant rate infusion $(3.5 \mathrm{mcg} / \mathrm{kg} / \mathrm{h})$. Horses breathed spontaneously during the whole procedure. Mean arterial blood pressure was maintained between 70 and $90 \mathrm{mmHg}$ with dobutamine $(<1.25 \mathrm{mcg} / \mathrm{kg} / \mathrm{min})$ and lactated ringer's solution $(5-10 \mathrm{ml} / \mathrm{kg} / \mathrm{h})$. All horses were administered $6-10 \mathrm{ml} / \mathrm{kg}$ hetastarch $(10 \%)$. For recovery, horses were lifted with a rescue sling into a hydropool $\left(37^{\circ} \mathrm{C}\right)$, the head was supported by an inflatable cushion. In order to increase the quality of recovery the horses were given $0.1 \mathrm{mg} / \mathrm{kg}$ morphine IM, $2 \mathrm{mcg} / \mathrm{kg}$ medetomidine IV and oxygen (15 I/min) intratracheally in the hydropool. Mean duration of anaesthesia was $251.4 \pm 90.2$ (97-540) minutes with no major anaesthetic complications. Mean duration of horses' recovery to a standing position outside the pool was $63 \pm 20$ (40-140) minutes. For one horse (withers height $185 \mathrm{~cm}$ ) the pool was not deep enough and the horse became excited during recovery in the hydropool. During assisted recovery in a conventional recovery box it refractured its radius and was euthanized. All other horses successfully recovered. Management as described provided excellent conditions.
\end{abstract}

Keywords: anaesthesia, equine fracture patient, medetomidine, hetastarch, rescue sling, hydropool recovery

\section{Narkosemanagement der Aufwachphase im Aufwachbecken bei 50 Pferden}

In dieser Studie werden retrospektiv Pferdeanästhesien beschrieben, welche infolge ihres zugrundeliegenden Problems eine Aufwachphase im Aufwachbecken benötigten. Ebenso werden mögliche Komplikationen diskutiert. Fünfzig Pferde (mittleres Alter $113.7 \pm 64.2$ Monate, mittleres Gewicht $479.3 \pm 115.3 \mathrm{~kg}$ ), welche aufgrund von Frakturen langer Röhrenknochen oder anderer orthopädischer Probleme operiert werden mussten, wurden in die Studie integriert. Neununddreißig der 50 Pferde wurden während 8-12 Stunden gefastet. Elf Pferde, welche als Notfall an der Pferdeklinik der Universität Zürich vorgestellt wurden, mussten sofort operiert werden. Intravenöse Antibiotika, Acepromazin $(0.03 \mathrm{mg} / \mathrm{kg} \mathrm{IM})$ und Phenylbutazon (4 mg/kg IV) wurden den Pferden 30-60 Minuten vor der Anästhesieeinleitung verabreicht. Die Pferde wurden mit Medetomidin (7 mcg/kg IV) sediert und die Anästhesie mit $2.2 \mathrm{mg} / \mathrm{kg} \mathrm{Ketamin} \mathrm{und} 0.02$ mg/kg Diazepam intravenös eingeleitet. Die Anästhesie wurde mit Isofluran (in Saverstoff und Luft) und mit einer konstanten Infusion Medetomidin (3.5 $\mathrm{mcg} / \mathrm{kg} / \mathrm{h}$ ) aufrechterhalten. Während der Anästhesie atmeten die Pferde spontan. Mithilfe von Dobutamin $(<1.25 \mathrm{mcg} / \mathrm{kg} / \mathrm{min})$ und Ringer Laktat $(5-10 \mathrm{ml} / \mathrm{kg} / \mathrm{h})$ wurde der mittlere arterielle Blutdruck zwischen 70 und $90 \mathrm{mmHg}$ aufrechterhalten. Alle Pferde erhielten intraoperativ $6-10 \mathrm{ml} / \mathrm{kg}$ Haes (10\%). Für die Aufwachphase wurden die Pferde mithilfe eines Bergungsnetzes in das Aufwachbecken (37 $\mathrm{C}$ ) transportiert. Um das Absinken des Kopfes zu verhindern, wurde der Kopf des Pferdes auf ein aufblasbares Kissen gelegt. Um eine gute und ruhige Aufwachphase zu gewährleisten, erhielten die Pferde $0.1 \mathrm{mg} / \mathrm{kg}$ Morphin IM, $2 \mathrm{mcg} / \mathrm{kg}$ Medetomidin IV und Sauerstoff (15 I/min) intratracheal. Die mittlere Anästhesiedauer betrug $251.4 \pm 90.2$ (97-540) Minuten. Bei keinem der Pferde kam es zu außerordentlichen Problemen während der Anästhesie. Die mittlere Aufwachdauer betrug $63 \pm 20$ (40-140) Minuten. Für ein Pferd (Widerristhöhe $185 \mathrm{~cm}$ ) war das Aufwachbecken vermutlich nicht tief genug und das Pferd regte sich während der Aufwachphase im Aufwachbecken stark auf. Während dem darauffolgenden assistierten Aufstellen in einer konventionellen Aufwachboxe refrakturierte der Radius des Pferdes und es musste euthanasiert werden. Alle anderen Pferde zeigten eine gute Aufwachphase im Aufwachbecken. Das verwendete Anästhesieprotokoll, bestehend aus Acepromazin, Medetomidin, Isofluran, Morphin und Stärkeinfusion (Hetastarch) ist ein gutes und sicheres Anästhesieprotokoll für Frakturpatienten mit anschließender Aufwachphase im Aufwachbecken.

Schlüsselwörter: Anästhesie, Pferd, Fraktur, Medetomidin, Haes, Bergungsnetz, Aufwachphase im Aufwachbecken, Wasserbecken

\section{Introduction}

It is well known that recovery is one of the most critical parts of equine anaesthesia and that it is often complicated by severe, life-threatening injuries. Recently published studies estimate the rate of perioperative equine fatalities to be 0.9 \% (Young et al. 1990, Johnston et al. 1991, Young et al. 1993, Johnston et al. 1995, Johnston et al. 1995, Johnston et al. 1996, Johnston et al. 2002, Johnston et al. 2004,
Bidwell et al. 2007). Results from a multicentre prospective study (CEPEF, Confidential Enquiry into Perioperative Equine Fatalities) reported that $23 \%$ of all deaths were associated with fractures during recovery (Johnston et al. 2004) Factors which contribute to this high fatality rate are the horse's natural tendency to stand and flight. This flight instinct often leads to an early attempt to stand up at a time when residual drug effects may produce incoordination and ataxia. If an exhausted, ataxic and stressed horse tries to stand up too 
early following surgery rough recoveries are often the consequence.

Different unassisted and assisted methods of recovery from anaesthesia are used to minimize the risk of severe injury during this phase. These include padded recovery stalls, heavy foam pads or inflatable air cushions, that inhibit the horse to stand up too early, head and tail ropes to stabilize the horse after standing and also different kinds of slings for assisted recovery (Fürst et al. 2006, Fürst et al. 2008). However, for horses recovering from anaesthesia for fracture repair surgery, such methods may provide insufficient safety. The hydropool may be a more suitable alternative to the standard recovery procedures and present with reduced rates of recovery injuries. The major benefit of recovering horses in a pool of water is that self-inflicted trauma and weight-bearing forces to surgically repaired bones are reduced. The partially submerged horse moves against the resistance of the water until it is fully capable of standing. This decreases the potential for severe injury that might occur when an ataxic and probably stressed horse wakes up from general anaesthesia.

Today, two different systems of water recovery are in use: the first is a pool raft system as it is used at the University of Pennsylvania (Sullivan et al. 2002) and the second is a hydropool system at the Washington State University (Tidwell et al. 2002) and at the University of Zurich.

The hydropool system consists of a small rectangular pool with a vertically movable floor, such that towards the end of recovery when the horse has regained standing power, the floor is moved upwards with the horse. With this method the still anaesthetized horse is placed inside the pool held by a sling and maintained in a sternal position. The head is secured in a horizontal position above the water level by several ropes. As the horse regains consciousness and the ability to stand, the pool's floor is raised, the sling is removed and the horse is walked into an adjacent padded recovery stall.

In this study, we retrospectively analysed the hydropool recovery of 50 horses. Due to the fractures, these horses were identified as high-risk patients for recovery-related injuries. The medical histories of these 50 horses were retrospectively analysed concerning quality of recovery, postoperative complications and survival rate.

\section{Materials and methods}

Data from 50 equine patients that underwent surgery for repair of different fractures were retrospectively analysed. These horses were presented to the Equine Hospital of the University of Zurich between August 2002 and January 2008. Data collected were breed, age, sex, weight, procedure, premedication, and the anaesthetic protocol. It was also noted if the horses underwent immediate surgery or were rested before anaesthesia. Complications associated with anaesthesia, surgery and pool recovery such as wound infections, pulmonary edema or myopathies and survival times and rates were also analysed in this study.

All horses were subjected to the following standard protocol: Whenever possible, horses were starved for 8-12 hours. Intra- venous antibiotics, acepromazine, $0.03 \mathrm{mg} / \mathrm{kg}$ IM (Prequillanâ ad us. vet., Arovet AG, Zollikon, Switzerland) and phenylbutazone, $4 \mathrm{mg} / \mathrm{kg}$ IV (Butadion ${ }^{\circledR}$ ad us. vet., Streuli AG, Uznach, Switzerland) were administered 30-60 minutes before anaesthesia induction. All horses were sedated with medetomidine, $7 \mathrm{mcg} / \mathrm{kg}$ IV (Domitor ${ }^{\circledR}$ ad us. vet., Dr. Graeub AG, Bern, Switzerland) and anaesthesia was induced with 2.2 $\mathrm{mg} / \mathrm{kg}$ ketamine (Narketan ${ }^{\circledR} 10$ ad us. vet., Vétoquinol AG, Belp, Switzerland) and $0.02 \mathrm{mg} / \mathrm{kg}$ diazepam IV (Valium ${ }^{\circledR} 10$ mg, Roche Pharma Switzerland AG, Reinach, Switzerland).

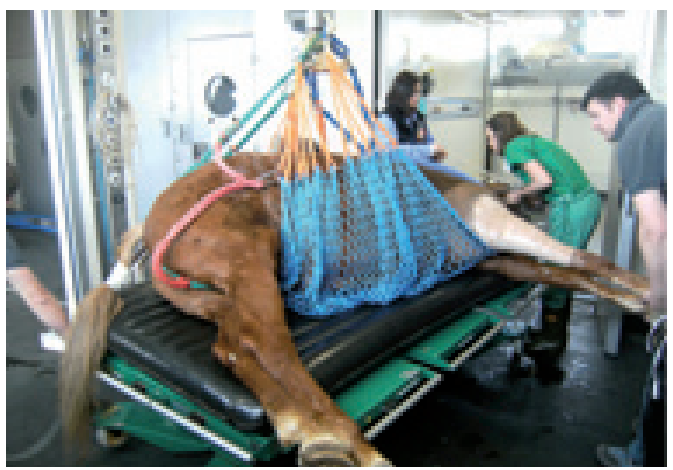

Fig. 1 A horse following repair of an olecranon fracture placed into a helicopter net for hydro-pool recovery.

Ein Pferd wird nach chirurgischer Behandlung einer Ulnafraktur mithilfe eines Helikopternetzes in das Aufwachbecken transportiert.

Anaesthesia was maintained with isoflurane (Attane ${ }^{\circledR}$ Isoflurane ad us. vet., Minrad INC., Buffalo, NY, USA) in oxygen and air and a constant rate infusion of medetomidine, 3.5 $\mathrm{mcg} / \mathrm{kg} / \mathrm{h}$ (Domitor ${ }^{\circledR}$ ad us. vet., Dr. Graeub AG, Bern, Switzerland). Inspired fraction of oxygen $\left(\mathrm{FiO}_{2}\right)$ was $0.45-0.55$ at the beginning of anaesthesia and increased to 0.9-1, if arterial partial pressure of oxygen $\left(\mathrm{paO}_{2}\right)$ was below $80 \mathrm{mmHg}$. Horses were allowed to breathe spontaneously. During anaesthesia, heart rate, respiratory rate, $\mathrm{SpO}_{2}$, arterial blood pressures and composition of in- and expired gases were continuously measured and recorded every 5 minutes. Arterial blood gases were measured every 30-60 minutes. Blood pressure was maintained during anaesthesia by administration of dobutamine, $<1.25 \mathrm{mcg} / \mathrm{kg} / \mathrm{min}$ (Dobutrex ${ }^{\circledR}$, Medika AG, Aesch, Switzerland) and lactated Ringer's solution (5$10 \mathrm{ml} / \mathrm{kg} / \mathrm{h}$ ) between $70-90 \mathrm{mmHg}$. Each horse further got 6-10 ml/kg hetastarch $10 \%$ administered over a period of 24 hours during the anaesthesia. In all horses a catheter was placed in the urinary bladder at the beginning of anaesthesia and left in place until the horse had recovered from the anaesthesia. Ten to twenty minutes before the end of anaesthesia, $0.1 \mathrm{mg} / \mathrm{kg}$ morphine (Morphin $\mathrm{HCl} 10 \mathrm{mg}$, Sintetica SA, Mendrisio, Switzerland) was administered IM.

For recovery horses were lifted with a rescue sling into a hydropool (water temperature $37^{\circ} \mathrm{C}$ ). A halter was placed on the head of the horse. A hoist was attached to the sling and the halter (see figure 1), and the horse was immerged into the pool. Inside the pool, the head of the horse was positioned on an inflatable cushion to avoid aspiration of water (see figure 2). The sling was maintained loosely around the horse with the majority of the horse's weight supported by the buoyancy. During pool recovery horses received lactated Ringer's solution $(2 \mathrm{ml} / \mathrm{kg} / \mathrm{h})$. As soon as the patients showed nystagmus or vigorous blinking of the eyes, they received $2 \mathrm{mcg} / \mathrm{kg}$ medetomidine IV (Domitor ${ }^{\circledR}$ ad us. vet., Dr. Graeub AG, Bern, Swit- 
zerland) (given slowly over 5 minutes). Oxygen (15 l/min) first was administered via the endotracheal tube and after extubation intranasally. Horses were extubated 10 minutes after the end of anaesthesia. Before extubation, $15 \mathrm{ml}$ of a phenylephrine solution $\left(0.15 \%\right.$ Ephedrin ${ }^{\circledR}$, nasal drops, G. Streuli \& Co. AG, Uznach, Switzerland) were instilled intranasally.

The features of the pool used are the following: It contains warmed and clean water $\left(37^{\circ} \mathrm{C}\right)$. It is $3.5 \mathrm{~m}$ long, $1.2 \mathrm{~m}$ wide and $2.5 \mathrm{~m}$ deep. Underwater lights help to see movements of

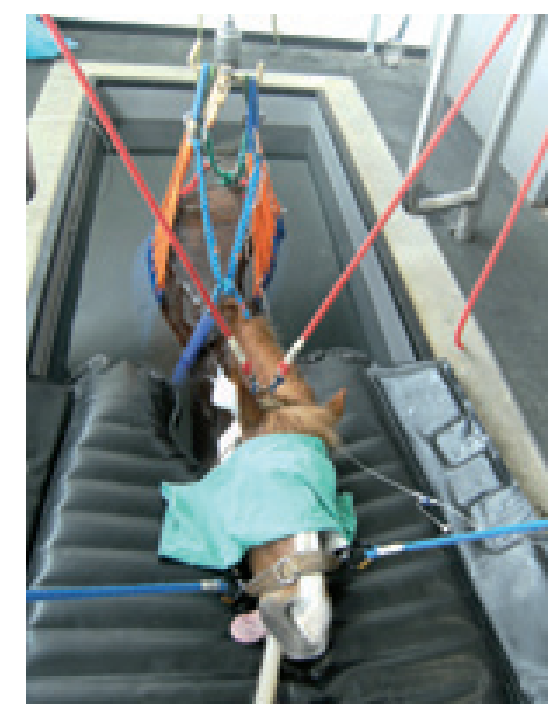

Fig. 2 Inside the pool the head of the horse is positioned on an inflatable cushion to avoid aspiration of water. On this figure the horse is still intubated. (front view).

Im Aufwachbecken wurde der Kopf des Pferdes auf ein aufblasbares Kissen gelegt, um Aspiration von Wasser zu vermeiden. Auf dieser Abbildung ist das Pferd immer noch intubiert (Vorderansicht).

the horses inside the pool and the position of their feet.

The anaesthetised horse is placed inside the pool restrained by a sling and maintained in a sternal position by a hoist. The head is secured in a horizontal position by several ropes. The perforated floor of the pool can be lifted up and like this the horses can be raised out of the water.

During recovery, the horses were kept in the centre of the pool until they started to bear weight on their limbs. They were left undisturbed until they showed purposeful movements of the limbs. If they did not show any movements until 60 minutes after the end of anaesthesia, they were encouraged to do so by the application of different stimuli. The hydraulic floor of the pool was initially raised until it just reached the buoyant horses' feet. This allowed the horses to not bear weight until they were fully awake. Once the patient was able to support weight on all four feet the hydraulic floor was raised and the horse lifted out of the water (see figure 3 and 4). During this process, the horses were supported with the hoist attached to the sling around the horses' body. The head was loosened for this lifting and manually supported by a horse handler. As soon as the floor of the pool reached to the level of the surrounding floor, bandages were removed and renewed. Then the patients were walked into an adjacent padded recovery stall, where they were dried using infrared heat lamps. Quality of recovery was assessed as excellent if the horse was quiet and did not show a lot of struggling, as good recovery if horses remained more or less quiet but showed struggling. And as bad recovery if an exhausted horse had to be removed from the pool.

Anaesthesia and recovery times were noted. Data were analysed using a commercially available software package (Statview $5.1{ }^{\circledR}$ software, SAS Inc. Cary, NC, USA). Data are reported as mean \pm standard error of mean (SEM) and in brackets the minimum and maximum value.

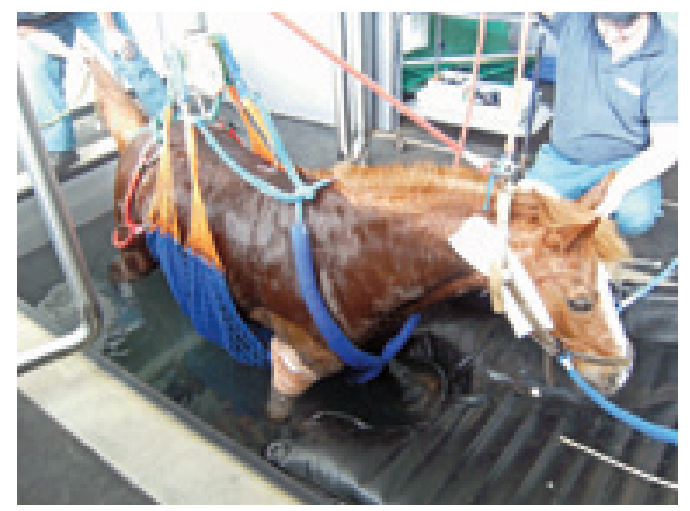

Fig. 3 Once the patient is able to support weight on all four feet the hydraulic floor is raised up and the horse is lifted out of the water (lateral view).

Wenn der Patient fähig ist auf allen Gliedmaßen Gewicht aufzunehmen, wird der Boden des Aufwachbeckens nach oben gefahren und das Pferd wird so aus dem Aufwachbecken gefahren (Seitenansicht).

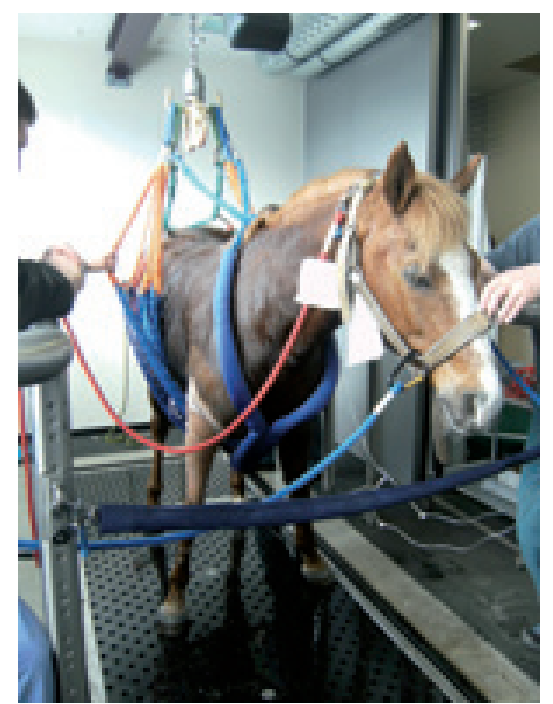

Fig. 4 The floor of the pool is raised to the level of the surrounding floor at the end of the hydro-pool recovery.

Am Ende der Aufwachphase im Aufwachbecken wurde der Boden des Aufwachbeckens bis zum Niveau des umliegenden Bodens hochgefahren.

\section{Results}

Fifty horses of a variety of breeds were included in this retrospective study. They were 32 warmblood, 7 thoroughbred, 2 Freiberger, 7 ponies and 1 Friesian horses. Mean age of the horses was 113.7 \pm 64.2 (3-241) months and mean weight was $479.3 \pm 115.3(200-750) \mathrm{kg}$. There were 20 females, 24 geldings and 6 intact males included in the study. 
The horses underwent surgical repair of the following: olecranon/ulna fractures (16), radius fractures (6), tibia fractures (4), patella fractures (3), fractures of the metacarpus (4) and metatarsus (4) and luxation of the superficial digital flexor tendon (3). One of each of the following procedures were also performed: orbita fracture, fracture of the talus, fracture of the central tarsal bone, fracture of the tuber coxae, fracture of the scapula, fracture of the tuberculum majus, comminuted fracture of the middle phalanx, severe varus deformity in the carpal joint and cervical stenotic myelopathy. Eleven of these fifty horses were presented as emergency cases requiring immediate intervention. These horses were not starved or rested before surgery. The remaining horses were starved 812 hours overnight.

There were differences between the horses concerning preoperative analgesia: Thirty-one horses received phenylbutazone ( $4 \mathrm{mg} / \mathrm{kg}$ ) IV as preoperative analgesia. Thirteen horses already had received phenylbutazone $(4 \mathrm{mg} / \mathrm{kg}$ ) IV once during the preceding night and there were 6 horses that had received phenylbutazone (2-4 mg/kg) PO over several days before surgery. Six of the emergency cases had phenylbutazone (4 $\mathrm{mg} / \mathrm{kg}$ ) as preoperative analgesia and the remaining five emergency cases received additional analgesia, consisting of butorphanol at different dose rates, and different $\alpha_{2}$-agonists for transport and preoperative diagnostic procedures.

Three horses received additional medetomidine before induction of anaesthesia to achieve a sufficient degree of sedation $(0.6 \mathrm{mcg} / \mathrm{kg}$ to $1.8 \mathrm{mcg} / \mathrm{kg} \mathrm{IV})$. There was one horse, which needed only $5 \mathrm{mcg} / \mathrm{kg}$ medetomidine to reach an adequate sedation. Another horse got additional butorphanol (20 $\mathrm{mcg} / \mathrm{kg} \mathrm{IV}$ ) and detomidine $(10 \mathrm{mcg} / \mathrm{kg} \mathrm{IV})$ to increase the degree of sedation. During anaesthesia, there was one horse, which received one litre of hetastarch $10 \%$ in addition to the already infused dose rate.

Mean heart rate during anaesthesia was $34.3 \pm 10.9$ beats/ min (18-63). Mean arterial blood pressure was $87 \pm 4.6$ $\mathrm{mmHg}$ (52-166). Mean arterial blood pressure fell transiently below $70 \mathrm{mmHg}$ in 8 horses. In these 8 horses mean arterial blood pressure was between 60 and $70 \mathrm{mmHg}$ for 5 to 65 minutes. In two horses mean arterial blood pressure fell below $60 \mathrm{mmHg}$. One of these two horses had a mean arterial blood pressure of $52 \mathrm{mmHg}$ during 5 minutes and the other had a mean arterial blood pressure of $56 \mathrm{mmHg}$ during 15 minutes. These hypotensive phases were treated by temporary reduction of isoflurane concentration and increase in lactated Ringer's solution administration. The mean arterial blood pressures (mean $\pm S D$ ) at different time points are represented in figure 5 .

Four of 157 samples taken for blood-gas analysis showed $\mathrm{paO}_{2}$ values below $60 \mathrm{mmHg}$. In 27 horses the inspired fraction of oxygen $\left(\mathrm{FiO}_{2}\right)$ was increased to above 0.55 . Three of the four hypoxemic arterial blood gas samples were from the same horse $\left(550 \mathrm{~kg}\right.$, left lateral recumbency, $\left.\mathrm{FiO}_{2}>0.9\right)$. The lowest $\mathrm{paO}_{2}$ of this horse obtained 80 minutes following induction of anaesthesia was $53 \mathrm{mmHg}\left(\mathrm{FiO}_{2}=0.91\right)$ and lasted for 35 minutes. Thereafter $\mathrm{paO}_{2}$ was above 60 until 225 minutes following induction of anaesthesia when the horse showed again a $\mathrm{paO}_{2}$ of $55 \mathrm{mmHg}\left(\mathrm{FiO}_{2}=0.91\right)$ for 35 minutes. The following paO2 was $59 \mathrm{mmHg}\left(\mathrm{FiO}_{2}=1\right)$ for the next 35 minutes. The next and also the last blood gas analysis of this horse showed then a $\mathrm{paO}_{2}$ of $60 \mathrm{mmHg}$ $\left(\mathrm{FiO}_{2}=1\right)$. The second horse, with a hypoxemic arterial blood gas showed a $\mathrm{paO}_{2}$ of $56 \mathrm{mmHg}\left(\mathrm{FiO}_{2}=1\right)$ at the end of surgery 185 minutes after induction of anaesthesia. However, both horses recovered uneventfully.

Mean duration of anaesthesia was $251.4 \pm 90.2$ (97-540) minutes. During surgery, thirty horses were positioned in right lateral recumbency, fifteen in left lateral recumbency and five horses were in dorsal recumbency. Mean duration of recovery to standing outside of the pool was $63 \pm 20$ (40-140) minutes. The quality of recovery in the hydropool was assessed as excellent in 44 horses, as good in 3 horses and bad in one horse. The remaining two horses were foals, which had to be moved out of the hydropool to the standard recovery box and required assisted recovery. The first foal was 5.5 months (bodyweight $215 \mathrm{~kg}$ ) with an olecranon fracture. The reason for assisted recovery was non-acceptance of the rescue sling. The second foal was 3.5 months old (bodyweight $200 \mathrm{~kg}$ ) with a cervical stenotic myelopathy. This foal required assisted recovery because it did not show any effort to stand up in the hydropool.

The horse with the bad pool recovery was a huge outstandingly naughty horse (withers height $185 \mathrm{~cm}$, bodyweight 750 $\mathrm{kg}$ ) that had undergone surgery for repair of a 3 weeks old radius fracture. Following two unsuccessful trials to recover this horse safely, it was decided to recover it in the normal recovery box to reduce risks to assisting personnel. During

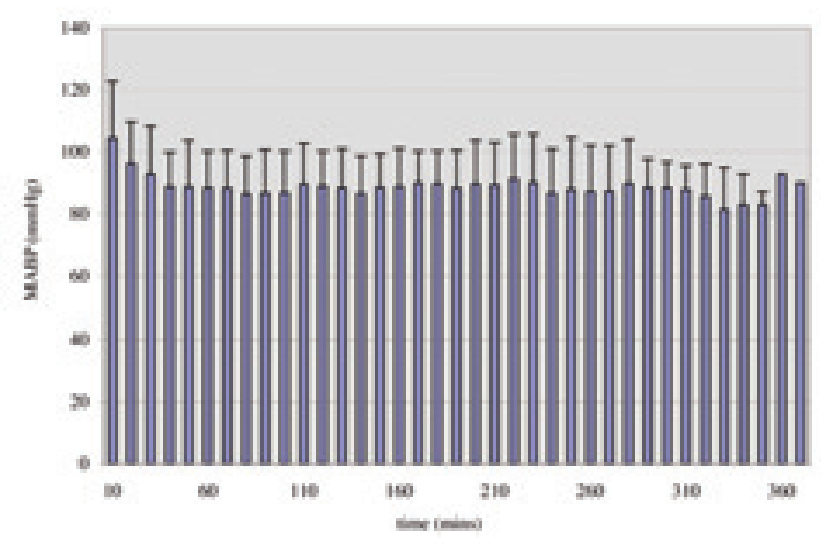

Fig. 5 The mean arterial blood pressures (mean $\pm \mathrm{SD}$ ) during anaesthesia, $n$ decreasing with time. Timepoint 0-90: $n=50$, timepoint 100: $n=48$, timepoint 110: $n=45$, timepoint 120: $n=43$, timepoint 140: $n=41$, timepoint 150: $n=40$, timepoint 160: $n=36$, timepoint 180: $n=32$, timepoint 190: $n=31$, timepoint 200: $n=27$, timepoint 210: $n=24$, timepoint 220: $n=21$, timepoint 230: $n=19$, timepoint 240: $n=17$, timepoint 250-260: $n=16$, timepoint 270: $n=12$, timepoint 280-290: $n=10$, timepoint 300: $n=8$, timepoint 310-320: $n=5$, timepoint 330: $n=4$, timepoint 340-350: $n=2$, timepoint 360-370: $n=1$

Mittlerer arterieller Blutdruck (Mittelwert \pm SD) während der Anästhesie, n nimmt mit der Zeit ab. Zeitpunkt 0-90: $n=50$, Zeitpunkt 100: $n=48$, Zeitpunkt 110: $n=45$, Zeitpunkt 120: $n=43$, Zeitpunkt 140: $n=41$, Zeitpunkt 150: $n=40$, Zeitpunkt 160: $n=36$, Zeitpunkt 180: $n=32$, Zeitpunkt 190: $n=31$, Zeitpunkt 200: $n=27$, Zeitpunkt 210: $n=24$, Zeitpunkt 220: $n=21$, Zeitpunkt 230: $n=19$, Zeitpunkt 240: $n=17$, Zeitpunkt 250-260: $n=16$, Zeitpunkt 270: $n=12$, Zeitpunkt 280-290: $n=10$, Zeitpunkt 300: $n=8$, Zeitpunkt 310-320: $n=5$, Zeitpunkt 330: $n=4$, Zeitpunkt 340-350: $n=2$, Zeitpunkt 360-370: $n=1$ 
assisted recovery, it refractured its radius and was euthanized immediately.

Four horses that seemed very exhausted received additional 0.5-1 ml/kg high energy hypertonic glucose infusion IV (Energidex ${ }^{\circledR}$ ad us. vet., Vétoquinol AG, Ittigen, Schweiz) during the recovery period in the hydropool and three of them were administered further hetastarch 10\% $(2-6 \mathrm{ml} / \mathrm{kg} \mathrm{IV})$. Only the horse with the bad recovery needed a supplemental sedation for a quiet recovery in the hydropool $(0.12 \mathrm{mg} / \mathrm{kg}$ xylazine IV). Two horses, which were reluctant to wake up after 60 minutes, received atipamezole during recovery, $0.06 \mathrm{mg} / \mathrm{kg}$ and $0.073 \mathrm{mg} / \mathrm{kg} \mathrm{IV}$.

Postoperative complications were suture infections $(n=6)$, bone infections $(n=8)$, combination of suture and bone infections $(n=1)$, joint infections $(n=1)$ and refractures $(n=1)$. In table 1, time periods between surgery and euthanasia of all patients with postoperative complications are noted. Eight horses died or had to be euthanized or slaughtered because of postoperative complications. Postoperative complications leading to death included bone infections $(n=6)$, radius fracture during recovery period $(n=1)$ and broken implants $(n=1)$. The shortest duration between pool recovery and death because of bone infection was one week and the longest was 15 weeks. The times of infection until dead of the aforementioned six horses are shown in figure 6. Two of these horses further showed radiological signs of laminitis. Three horses were euthanized for reasons not related to surgery or pool recovery.

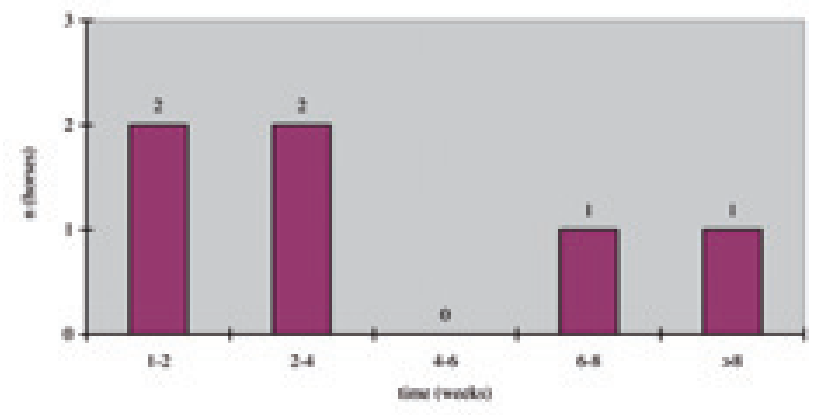

Fig. 6 Timeperiod from pool recovery until death in horses with bone infections

Zeitspanne zwischen Aufwachphase im Aufwachbecken und Tod derjenigen Tiere mit Knocheninfekten.

\section{Discussion}

The present study evaluated retrospectively the use of a hydropool for recovery of horses following surgical fracture repair. One out of fifty horses did not recover successfully with this system, which is considered a remarkable result, considering the fact that mean anaesthesia time was over 4 hours and all surgeries major.

The rate of equine fatalities directly related to anaesthesia ranges from 0.12-1\% (Young et al. 1990; Johnston et al. 1991; Young et al. 1993; Johnston et al. 1995, Johnston et al. 1995, Johnston et al. 1996, Johnston et al. 2002, Johnston et al. 2004, Bidwell et al. 2007). This is much hig- her than the rate described in companion animals $(0.11 \%$ (Dyson et al. 1998), 0.17\%-0.24\% (Brodbelt et al. 2008), $0.1 \%-0.2 \%$ (Brodbelt et al. 2008)) or human patients (0.008\% (Lagasse et al. 2002)).

In the study of Bidwell et al. (2007), the incidence of perianaesthetic fatalities in horses (0.12\%) was almost 10 fold lower than in the other above cited studies. The reason is, that in Bidwell's study mainly shorter surgeries with a duration of less than one hour were performed. Already in 1995, Johnston et al. have shown that in equine anaesthesia risk of fatality increases exponentially with increasing duration of anaesthesia (Johnston et al. 1995). If anaesthesia duration was more than 4 hours fatality risk increased 7.6 fold in comparison to an anaesthesia duration of up to 90 minutes. Johnston et al. further showed that the anaesthesia risk for fracture repair in equine patients is higher than for any other surgical category.

An optimal recovery phase is essential for equine fracture patients (Johnston et al. 2002). For this purpose the use of a hydropool is an alternative to the standard recovery procedures. In water, stress and weight-bearing forces to surgically repaired bones can be reduced and thus immediate postoperative collapse of repaired fractures avoided.

The first pool system to be reported is a pool-raft system located at the University of Pennsylvania (Sullivan et al. 2002). It consists of a large round recovery pool and a raft, into which the anaesthetised horse is placed by the use of a sling. The use of a raft in conjunction with the pool allows flotation of the horse. In 2002, Sullivan et al. evaluated retrospectively the use of this system in 393 horses on 471 occasions. In this study, in $13 \%$ of the horses minor complications such as respiratory tract complications and wetting of bandages or casts occurred. Unfortunately, it was not reported if wound infections occurred as a consequence of this. A total of $3 \%$ of the horses had to be euthanized ( 9 horses with failure of internal fixation) or died (1 horse following water aspiration) as a direct consequence of the pool recovery. This number seems high in comparison to our results especially if the relatively low mean anaesthesia time of 156 minutes in the report of Sullivan et al. (2002) is taken into consideration.

The other pool system to recover horses is slightly different. It is a hydropool system into which the horses are submerged inside slings or a helicopter rescue net. One of these systems is located in Washington State University and the other one is the one that was used for the present study. Up to date, the most important complication during hydropool recovery reported was pulmonary oedema (Tidwell et al. 2002). Following a mean anaesthesia duration of 182 minutes, ten horses out of 60 (16.6\%) developed some degree of pulmonary oedema and in three horses it was considered severe. One horse died (1.7\%) as a consequence of this.

Submerging the horse into water results in increased extrathoracic pressure, a reflection of the displaced water and resultant hydrostatic pressure. The effects of increased hydrostatic pressure on the cardiovascular and pulmonary system in horses are not well understood. Richter et al. (2001) tried to measure the effects on the cardiopulmonary system of submerging a horse in a sling into the water. They showed that pulmonary pressures increase considerably. She concluded 
that the increased effort needed to overcome the extrathoracic hydrostatic effects of immersion in combination with the increased pulmonary arterial pressure might contribute to an increased incidence of pulmonary oedema in horses during anaesthetic recovery in a hydropool.

Several studies involving humans and dogs have closely examined the cardiovascular and pulmonary changes induced by submersion into water (Moutet et al. 1992, Allison et al. 1993, Nakamura et al. 1996, Miwa et al. 1997). Partial submersion of a mammal into water results in an equilibration of hydrostatic pressure gradients of body fluids (Choukroun et al. 1989). The increased hydrostatic pressure leads to a shift in blood flow from the periphery to the intrathoracic region, thereby increasing pulmonary capillary blood volume and left cardiac preload (Choukroun et al. 1983, Norsk et al. 1985). Combination of an increased cardiac preload with an overhydration could increase the incidence of pulmonary oedema.

In contrast to the studies of Tidwell et al. (2002) and Sullivan et al. (2002), we report no case of pulmonary oedema. In contrast to the study of Tidwell et al. (2002) every horse in our study received crystalloid and colloid solutions concurrently. With the aid of colloid solutions we increased the colloid osmotic pressure and thereby may have helped to decrease the incidence of pulmonary oedema. Tidwell et al (2002) mentioned also that pulmonary function is compromised by prolonged anaesthesia and might exacerbate when horses are submerged into water for recovery. This is possible but in our opinion not the major determinant. In our study, total anaesthesia time was considerably longer (251.4 \pm 90.2 minutes) than in the studies of Tidwell et al. (2002) (182 minutes) or Sullivan et al. (2002) (156 minutes). To optimise quality of recovery the administration of $\alpha_{2}$-agonists to horses may represent a suitable method (Santos et al. 2003). Boli of $\alpha_{2}$-agonists cause initially a major increase in arterial blood pressures. To avoid an excessive increase in pulmonary arterial blood pressures during submersion of the horse into the water, we administered the $\alpha_{2}$-agonist over several minutes. Furthermore, all horses received acepromazine preoperatively, which is a potent long acting vasodilator that probably helps to reduce peak pulmonary pressures.

Lung oedema can also be caused by an increased resistance to breathing as encountered for example with swollen nasal mucosa following long surgeries (Kollias-Baker et al. 1993, Ball et al. 1996, Tute et al. 1996). This could be avoided by maintaining the airway patent with an endotracheal tube. We choose to use decongestive nasal drops instead and extubated the horses for recovery in order to reduce the risk of water aspiration and to minimally disturb the horse during the recovery period.

Success rate of fracture repair is dependent on many factors. A major determinant is certainly the kind and location of the fracture but also the weight, the age, the temperament and the usage of a horse will have an influence. Further the surgeon, the surgical technique as well as available equipment will influence outcome.

These factors differ considerably between different centres and therefore direct comparison of the present study with other studies is not possible. Infections are a major complication following internal fixation in horses. As protection of the surgery site is difficult when horses are submerged into water immediately following surgery an increased incidence of infection could be a consequence. The other two pool recovery studies (Sullivan et al. 2002, Tidwell et al. 2002) showed lower incidences of infections but the anaesthesia time was much shorter and less invasive surgeries were performed. Longer surgeries carry an increased risk of infection (Brown et al. 1997, Beal et al. 2000, Nicholson et al. 2002, Eugster et al. 2004, Leong et al. 2006). In a study with a case selection comparable to our study, in $32 \%$ of the horses incisional infections and in $19 \%$ implant infections occurred (Levine et al. 2007) but only $6 \%$ of the horses had to be euthanized as a consequence of the infection. In this study, 55 $\%$ of the horses were recovered in a pool-raft system, which was not associated with an increased rate of infection. Another study (Denny et al. 1987) of olecranon fracture repair reported 8 infections in 21 cases but only one euthanasia $(4.7 \%)$ as a consequence of this.

Another fatal complication, which might occur in horses following fracture repair, is laminitis. In our study, two out of fifty horses showed radiologically verifiable signs of laminitis, both had to be euthanized because of bone infections. Laminitis is a known complication after colic (Hunt et al. 1986) or orthopaedic surgery in horses (Peloso et al. 1996, Levine et al. 2007, Widmer et al. 2009). In most orthopaedic patients, excessive weight bearing of the controlateral limb is thought to contribute to the development of laminitis (Peloso et al. 1996). In a retrospective study on the clinical use of the locking compression plate (LCP) for long bone fractures and arthrodesis, five of 31 horses developed laminitis in the controlateral limb and four of these had to be euthanised (Levine et al. 2007). In another study, which retrospectively analysed limb cellulitis in 44 horses, eight horses developed laminitis in the contralateral limb and were euthanized (Adam et al. 2007). Currently, the pathophysiology of laminitis remains unclear. Either hyperperfusion of the digit allows destructive enzymes to access the lamella (Pollitt et al. 1996, Moore et al. 2004) or hypoperfusion followed by reperfusion leads to laminar ischemia and cellular damage (Hood et al. 1999, Moore et al. 2004). It was shown that the early stages of laminitis are associated with dysfunction of the laminar microvasculature (Peroni et al. 2006). In fact these authors showed, that laminar veins were more sensitive to different vasoconstrictive substances than laminar arterioles. These results indicate that there may be a predisposition for venoconstriction within the vasculature of the equine digit. While this physiological predisposition for venoconstriction may be important in the regulation of the blood flow during exercise, it also may help to explain why laminitis can result from a variety of pathological systemic conditions.

Other major complications following long anaesthesia in horses are myopathies and neuropathies. It is well known that maintenance of cardiovascular function and perfusion of large muscle groups and nerves plays an important role in the prevention of myopathy and neuropathy (Grandy et al. 1987, Lindsay et al. 1989, Johnston et al. 2004, Franci et al. 2006). Assessment of perfusion during clinical anaesthesia is difficult and not common practice. However, arterial 
blood pressure is clinically measured and used as an indicator of circulatory function. It is generally assumed that maintenance of mean arterial blood pressure above 60-70 $\mathrm{mmHg}$ is crucial for the prevention of myopathy formation (Lindsay et al. 1989, Richey et al. 1990, Duke et al. 2006, Bidwell et al. 2007). In our study, with the aid of hetastarch and dobutamine mean arterial blood pressure $(87 \pm 4.6$ $\mathrm{mmHg}$ ) was much higher than in the study of Tidwell et al. (Tidwell et al. 2002) (67 mmHg). The lowest measured mean arterial blood pressure of our study was $52 \mathrm{mmHg}$ during 5 minutes whereas the lowest measured mean arterial blood pressure in the study of Tidwell et al. was $40 \mathrm{mmHg}$ during an unknown time period. Tidwell et al. (2002) reported myopathy/neuropathy in 3 of sixty horses following pool recoveries but unfortunately did not report whether those were the horses with low blood pressures or not. In our study, no myopathy/neuropathy was observed probably as a consequence of good cardiovascular function achieved with the aid of colloid solutions and dobutamine. In our study, the use of acepromacine, might have further helped to prevent local vasoconstriction. It is possible that we thereby managed to prevent underperfusion of certain muscle groups and thus formation of myopathies.

In the present study, we retrospectively analysed the use of a hydropool system for recovery of horses following fracture repair of major orthopaedic surgery. The used anaesthesia management helped to prevent pulmonary oedema as well as myopathy formation. All but one horse were successfully recovered following major fracture repair of considerable duration. However $12 \%$ of all horses had to be euthanized as a consequence of postoperative infections. It is unclear if this was a consequence of the use of the pool for recovery or the long duration of surgery. The overall good survival rate following major fracture surgery of very long duration favours the use of the described hydropool system.

\section{Literature}

Adam E. N. and Southwood L. L. (2007) Primary and secondary limb cellulitis in horses: 44cases (2000-2006). J. Am. Vet. Med. Assoc. 231, 1696-1703

Allison T. G., Miller T. D., Squires R. W. and Gau G. T. (1993) Cardiovascular responses to immersion in a hot tub in comparison with exercise in male subjects with coronary artery disease. Mayo Clinic Proceedings 68, 19-25

Ball M. A. and Trim C. M. (1996) Post anaesthetic pulmonary edema in two horses. Equine Vet. Educ. 8, 13-16

Beal M. W., Brown D. C. and Shofer F. S. (2000) The effects of perioperative hypothermia and the duration of anaesthesia on postoperative wound infection rate in clean wounds: a retrospective study. Vet. Surg. 29, 123-127

Bidwell L. A., Bramlage L. R. and Rood W. A. (2007) Equine perioperative fatalities associated with general anaesthesia at a private practice-a retrospective case series. Vet. Anaesth. Analg. 34, 23-30

Brodbelt D. (2009) Perioperative mortality in small animal anaesthesia. Vet. J. 182, 152-161

Brodbelt D. C., Blissitt K. J., Hammond R. A., Neath P. J., Young L. E., Pfeiffer D. U. and Wood J. L. (2008) The risk of death: the confidential enquiry into perioperative small animal fatalities. Vet. Anaesth. Anal. 35, 365-373

Brown D. C., Conzemius M. G., Shofer F. and Swann H. (1997) Epidemiologic evaluation of postoperative wound infections in dogs and cats. J. Am. Vet. Med. Assoc. 210, 1302-1306 
Choukroun M. L., Guenard H. and Varene P. (1983) Pulmonary capillary blood volume during immersion in water at different temperatures. Undersea Biomed. Res. 10, 331-342

Choukroun M. L., Kays C. and Varene P. (1989) Effects of water temperature on pulmonary volumes in immersed human subjects. Respir. Physiol. 75, 255-265

Denny H. R., Barr A. R. S. and Waterman A. (1987) Surgical treatment of fractures of the olecranon in the horse: A comparative review of 25 cases. Equine Vet. J. 19, 319-325

Duke T., Filzek U., Read M. R., Read E. K. and Ferguson J. G. (2006) Clinical observations surrounding an increased incidence of postanaesthetic myopathy in halothane-anaesthetized horses. Vet. Anaesth. Analg. 33, 122-127

Dyson D. H., Maxie M. G. and Schnurr D. (1998) Morbidity and mortality associated with anaesthetic management in small animal veterinary practice in Ontario. J. Am. Animal Hosp. Assoc. 34, 325-335

Eugster S., Schawalder P., Gaschen F. and Boerlin P. (2004) A prospective study of postoperative surgical site infections in dogs and cats. Vet. Surg. 33, 542-550

Franci P., Leece E. A. and Brearley J. C. (2006) Post anaesthetic myopathy/neuropathy in horses undergoing magnetic resonance imaging compared to horses undergoing surgery. Equine Vet. J. 38, 497-501

Fürst A. E., Keller R. and von Salis B. (2006) Entwicklung eines verbesserten Hängegeschirrs für Pferde: Das Tier-Bergungs- und Transportnetz (TBTN). Pferdeheilkunde 22, 767-772

Fürst A. E., Keller R., Kummer M., Manera C., von Salis B., Auer J. and Bettschart-Wolfensberger R. (2008) Evaluation of a new fullbody animal rescue and transportation sling in horses: 181 horses (1998-2006). J. Vet Emerg. Crit. Care. 18, 619-625

Grandy J. L., Steffey E. P., Hodgson D. S. and Woliner M. J. (1987) Arterial hypotension and the development of postanaesthetic myopathy in halothane-anaesthetized horses. Am. J. Vet. Res. 48, 192-197

Hood D. M. (1999) The pathophysiology of developmental and acute laminitis. Vet. Clin. North Am. Equine Pract. 15, 321-343

Hunt J. M., Edwards G. B. and Clarke K. W. (1986) Incidence, diagnosis and treatment of postoperative complications in colic cases. Equine Vet. J. 18, 264-270

Johnston G. M. (1991) Confidential enquiry into perioperative equine fatalities. Equine Vet. Educ. 3, 5-6

Johnston G. M. (1995) The risks of the game: the confidential enquiry into perioperative equine fatalities. Br. Vet. J. 151, 347-350

Johnston G. M., Eastment J. K., Taylor P. M. and Wood J. L. (2004) Is isoflurane safer than halothane in equine anaesthesia? Results from a prospective multicentre randomised controlled trial. Equine Vet. J. 36, 64-71

Johnston G. M., Eastment J., Wood J. L. and Taylor P. M. (2002) The confidental enquiry into perioperative equine fatalities (CEPEF): mortality results of phases 1 and 2. Vet. Anaesth. Analg. 29, 159-170

Johnston G. M., Taylor P. M., Holmes M. A. and Wood J. L. (1995) Confidential enquiry of perioperative equine fatalities (CEPEF-1): preliminary results. Equine Vet. J. 27, 193-200

Johnston G. M., Taylor P. M., McGee M. A., Holmes M. A. and Wood J. L. (1996) The confidential enquiry into perioperative fatalities (CEPEF-1). Survival curves. Vet. Surg. 25, 182

Kollias-Baker C. A., Pipers F. S., Heard D. and Seeherman H. (1993) Pulmonary edema associated with transient airway obstruction in three horses. J. Am. Vet. Med. Assoc. 202, $1116-1118$

Lagasse R. S. (2002) Anaesthesia safety: model or myth? A review of the published literature and analysis of current original data. Anesthesiology 97, 1609-1617

Leong G., Wilson J. and Charlett A. (2006) Duration of operation as a risk factor for surgical site infection: comparison of English and US data. J. Hosp. Infect. 63, 255-262

Levine D. G. and Richardson D. W. (2007) Clinical use of the locking compression plate (LCP) in horses: a retrospective study of 31 cases (2004-2006). Equine Vet. J. 39, 401-406

Lindsay W. A., Robinson G. M., Brunson D. B. and Majors L. J. (1989) Induction of equine postanaesthetic myositis after halothane-induced hypotension. Am. J. Vet. Res. 50, 404-410
Miwa C., Sugiyama Y., Mano T., Iwase S. and Matsukawa T. (1997) Sympatho-vagal responses in humans to thermoneutral head-out water immersion. Aviat. Space Environ. Med. 68, 1109-11114

Moore R. M., Eades S. C. and Stokes A. M. (2004) Evidence for vascular and enzymatic events in the pathophysiology of acute laminitis: which pathway is responsible for initiation of this process in horses? Equine Vet. J. 36, 204-209

Moutet J., Pinaud M., Zaouter M., Le Floch R., Fourret P., Meignier M. and Pannier M. (1992) [Hemodynamic effects of bathing in severe burnt patients]. Ann. Fr. Anaesth. Reanim. 11, 410-414

Nakamura K., Takahashi H., Shimai S. and Tanaka M. (1996) Effects of immersion in tepid bath water on recovery from fatigue after submaximal exercise in man. Ergonomics 39, 257-266

Nicholson M., Beal M., Shofer F. and Brown D. C. (2002) Epidemiologic evaluation of postoperative wound infection in clean-contaminated wounds: A retrospective study of 239 dogs and cats. Vet. Surg. 31, 577-581

Norsk P., Bonde-Petersen F. and Warberg J. (1985) Central venous pressure and plasma arginine vasopressin during water immersion in man. Eur. J. Appl. Physiol. Occup. Physiol. 54, 71-78

Peloso J. G., Cohen N. D., Walker M. A., Watkins J. P., Gayle J. M. and Moyer W. (1996) Case-control study of risk factors for the development of laminitis in the contralateral limb in equidae with unilateral lameness. J. Am. Vet. Med. Assoc. 209, 1746-1749

Peroni J. F., Moore J. N., Noschka E., Grafton M. E., Aceves-Avila M., Lewis S. J. and Robertson T. P. (2006) Predisposition for venoconstriction in the equine laminar dermis: implications in equine laminitis. J. Appl. Physiol. 100, 759-763

Pollitt C. C. (1996) Basement membrane pathology: a feature of acute equine laminitis. Equine Vet. J. 28, 38-46

Richey M. T., Holland M. S., McGrath C. J., Dodman N. H., Marshall D. B., Court M. H., Norman W. M. and Seeler D. C. (1990) Equine post-anaesthetic lameness. A retrospective study. Vet. Surg. 19, 392-397

Santos M., Fuente M., Garcia-lturralde R., Herran R., Lopez-Sanroman J. and Tendillo F. J. (2003) Effects of alpha-2 adrenoceptor agonists during recovery from isoflurane anaesthesia in horses. Equine Vet. J. 35, 170-175

Sullivan E. K., Klein L. V., Richardson D. W., Ross M. W., Orsini J. A. and Nunamaker D. M. (2002) Use of a pool-raft system for recovery of horses from general anesthesia: 393 horses (1984-2000). J. Am. Vet. Med. Assoc. 221, 1014-1018

Tidwell S. A., Schneider R. K., Ragle C. A., Weil A. B. and Richter M. C. (2002) Use of a hydro-pool system to recover horses after general anesthesia: 60 cases. Vet. Surg. 31, 455-461

Tute A. S., Wilkins P. A., Gleed R. D., Credille K. M., Murphy D. J. and Ducharme N. G. (1996) Negative pressure pulmonary edema as a post-anaesthetic complication associated with upper airway obstruction in a horse. Vet. Surg. 25, 519-523

Widmer A., Kummer M., Bettschart-Wolfensberger R. and Fürst A. E. (2009) Atypical laminitis after orthopedic surgery in eight horses. Pferdeheilkunde 25, 576-580

Young S. S. and Taylor P. M. (1990) Factors leading to serious anaesthetic related problems in equine anaesthesia. Vet. Anaesth. Analg 17, 59

Young S. S. and Taylor P. M. (1993) Factors influencing the outcome of equine anaesthesia: a review of 1314 cases. Equine Vet. J. 25, 147-151

Dr. med. vet. Stephanie Picek

Equine Departement, Section Anaesthesia

Vetsuisse-Faculty Zurich

Winterthurerstrasse 260

8057 Zurich

Switzerland

spicek@vetclinics.uzh.ch 